\title{
Use of anatomical root markers for species identification in Catasetum (Orchidaceae) at the Portal da Amazônia region, MT, Brazil
}

\author{
Ivone Vieira da SILVA ${ }^{*}$, Rubens Maia de OLIVEIRA ${ }^{1}$, Ana Aparecida Bandini ROSSI ${ }^{1}$, \\ Angelita Benevenuti da SILVA ${ }^{1}$, Daiane Maia de OLIVEIRA² \\ Universidade do Estado de Mato Grosso, Campus Universitário de Alta Floresta. Faculdade de Ciências Biológicas e Agrárias, BR 208, km 147, CEP 78580-000, Alta Floresta, Mato \\ Grosso, Brasil. \\ 2 Universidade Estadual de Montes Claros, Departamento de Biologia, Avenida Rui Braga, Vila Mauriceia, CEP 39401-089, Montes Claros, Minas Gerais, Brasil. \\ * Corresponding author: ivibot@hotmail.com
}

\begin{abstract}
Orchidaceae is one of the largest botanical families, with approximately 780 genera. Among the genera of this family, Catasetum currently comprises 166 species. The aim of this study was to characterize the root anatomy of eight Catasetum species, verifying adaptations related to epiphytic habit and looking for features that could contribute to the vegetative identification of such species. The species studied were collected at the Portal da Amazônia region, Mato Grosso state, Brazil. The roots were fixed in FAA 50, cut freehand, and stained with astra blue/fuchsin. Illustrations were obtained with a digital camera mounted on a photomicroscope. The roots of examined species shared most of the anatomical characteristics observed in other species of the Catasetum genus, and many of them have adaptations to the epiphytic habit, such as presence of secondary thickening in the velamen cell walls, exodermis, cortex, and medulla. Some specific features were recognized as having taxonomic application, such as composition of the thickening of velamen cell walls, ornamentation of absorbent root-hair walls, presence of tilosomes, composition and thickening of the cortical cell walls, presence of mycorrhizae, endodermal cell wall thickening, the number of protoxylem poles, and composition and thickening of the central area of the vascular cylinder. These traits are important anatomical markers to separate the species within the genus and to generate a dichotomous identification key for Catasetum. Thus, providing a useful tool for taxonomists of this group.
\end{abstract}

KEYWORDS: adaptations, Catasetinae, epiphyte, velamen

\section{Uso de marcadores anatômicos radiculares para a determinação de espécies de Catasetum (Orchidaceae) da Região do Portal da Amazônia, MT, Brasil}

\begin{abstract}
RESUMO
Orchidaceae é uma das maiores famílias botânicas, com cerca de 780 gêneros. Dentre seus gêneros, Catasetum inclui atualmente 166 espécies. Caracterizou-se a raiz de oito espécies de Catasetum com o objetivo de verificar caracteres relacionados ao hábito epifítico e contribuir para a taxonomia do grupo. As espécies foram coletadas na regiáo do Portal da Amazônia, no norte do estado de Mato Grosso. Raízes foram fixadas em FAA 50 (1:1:8 formaldeído, ácido acético glacial e álcool etílico 50\%), cortadas à máo livre e corados com azul de astra e fucsina. As ilustraçóes foram obtidas por meio do capturador de imagens acoplado ao fotomicroscópio. As raízes das espécies estudadas compartilharam a maioria dos caracteres anatômicos observados em outras espécies de Catasetum, e vários destes demonstraram adaptaçôes ao hábito epifítico, tais como presença de espessamento secundário na parede das células do velame, da exoderme, do córtex e da medula. Alguns caracteres foram reconhecidos como tendo aplicaçáo taxonômica, como composição do espessamento da parede das células do velame, ornamentaçáo da parede dos pelos absorventes, presença de tilossomos, composiçáo e espessamento da parede das células do córtex, presença de micorriza, tipo de espessamento da parede das células da endoderme, número de pólos de protoxilema e composição e tipo de espessamento da região central do cilindro vascular. Esses caracteres são importantes marcadores anatômicos, pois possibilitam separar as espécies dentro do gênero e gerar uma chave dicotômica de identificação para as Catasetum da regiáo investigada, fornecendo, assim, uma ferramenta útil para os taxonomistas do grupo.
\end{abstract}

PALAVRAS-CHAVE: Epífita, velame, adaptaçóes, Catasetinae 


\section{INTRODUCTION}

Orchidaceae is one of the largest families of flowering plants in the superorder Liliiflorae, and consists of about 780 genera. The Orchidaceae contains approximately 25,000 species (Pridgeon et al. 2009). Chase et al. (2003) divided these species into five subfamilies: Apostasioideae, Vanilloideae, Cypripedioideae, Orchidoideae, and Epidendroideae. They grow in cold and hot climates and temperate regions, but can be found in greater abundance in both number and diversity in tropical regions (Englert 2000).

The subtribe Catasetinae (Epidendroideae) comprises seven genera (Pridgeon et al. 2009). Among these genera we find Catasetum, which was described by L. C. Richard Kunth in 1822. This genus includes 166 species distributed in South and Central America, 67 of them occurring in Brazil.

Catasetum has epiphytic species that develop mainly on tree tops. The leaves of these species are deciduous in the dry season while roots and pseudobulbs are always present. The anatomical characteristics of these vegetative organs are continuously accessible, thereby potentially useful in vegetative identification. Anatomy of the vegetative organs has been applied for at least 150 years, enabling both phylogenetic inferences and species identification.

Portal da Amazônia encompasses the municipalities Alta Floresta, Apiacás, Carlinda, Colíder, Guarantã do Norte, Marcelândia, Matupá, Nova Bandeirantes, Nova Canaã do Norte, Nova Guarita, Nova Monte Verde, Nova Santa Helena, Novo Mundo, Paranaíta, Peixoto de Azevedo, and Terra Nova. This region typically features ombrophilous forest biomes, with both wet and dry seasons, and has a great diversity of orchids. Catasetum is among the most frequent. This genus is appreciated for domestic landscaping. The immense deforestation of the Amazon and the removal of many Amazonian orchid species due to their commercial value intensify the disappearance of natural habitats of many species, such as those of Catasetum (Pedroso-de-Moraes et al. 2012).

There are few studies on Catasetum in the Amazon. Stern and Judd (2001) anatomically characterized the vegetative organs of species of the subtribe Catasetinae, and Pedrosode-Moraes et al. (2012) described the root anatomy of 12 representatives of Catasetinae. In this context, the aim of this study was to describe the root anatomy of eight Catasetum species, verifying adaptations related to epiphytic habit and looking for features that could contribute to the vegetative identification of such species.

\section{MATERIALS AND METHODS}

This study was conducted at the Universidade do Estado de Mato Grosso - UNEMAT, Campus Universitário de Alta Floresta, MT. Roots from eight epiphytic species of the genus Catasetum (Orchidaceae, Catasetinae) were used. The species were: Catasetum $x$ apolloi Benelli \& Grade, $C$. fimbriatum Lindl, C. juruenense Hoehne, C. longifolium Lindley, C. matogrossense Bicalho, C. osculatum Lacerda \& P. Castro, C. saccatum Lindl, and C. schmidtianum Miranda \& Lacerda. They were collected at the Portal da Amazônia region and taken to the Chácara Recanto das Orquídeas, located at Perimetral Auxiliar Oeste on the urban perimeter of Alta Floresta (56\%05'44.5"W and 09052'34.2”S). The Portal da Amazônia region has a hot, humid equatorial climate, characterized by a rainy season and a dry season. The vegetation is characterized as Amazon rainforest in a section of the Amazon Basin.

For the anatomical study, root samples were obtained at about $1 \mathrm{~cm}$ from the rhizome from a minimum of three individuals of each species collected in different populations. The roots were fixed in FAA 50 and preserved in ethanol $70 \%$. Cross and longitudinal sections were made free-hand by cutting with a razor blade, washed, stained with Astra blue and basic fuchsin, and mounted on semi-permanent slides with glycerol jelly (Kaiser 1880).

Some sections of fresh material were used for histochemical analysis. In particular, starch was identified with Lugol, lipids with Sudan IV, lignin with an acid-phloroglucin and safranin solution, cellulose with Astra blue (Johansen 1940). Steinmetz reagent were used for the recognition of cellular constituents, such as starch, cellulose, lignin, suberin, various lipids, latex, resin duct, and cutin (Costa et al. 2002), and confirming with chlor-zinc-iodine (Costa 1972), thionine (Costa 1972), flavonoids by potassium hydroxide (Costa 1982), and methylene blue solution to verify the presence of mucilage (Langeron 1949).

The illustrations were obtained with a digital camera mounted on a photomicroscope (Leica DMLB, Wetzlar, Germany). The program Leica IM50 was used in this step. After that, a dichotomous key was created, seeking to highlight the diagnostic anatomical characteristics that were detected.

\section{RESULTS}

The roots presented velamen, a differentiated cortex, uniseriate endodermis and pericycle, and a polyarch vascular cylinder (Figures 1A-G). The velamen varies in the number of cell layers and in the structure of their walls (Figures 1 A-G, 2A, 2D). In all species studied, the velamen cell wall thickens from tenuous spirals of cell wall material; this may be cellulosic as seen in Catasetum fimbriatum, $C$. matogrossense, and C. schmidtianum (Figure 2D) or lignified in C. apolloi, C. juruenense, C. longifolium, C. osculatum, and C. saccatum (Figure 2A). 
In all studied species, a peripheral layer of the velamen differentiates into an epivelamen in which cell walls are cellulosic (Figures 2A, 2D). The studied species have absorbent unicellular root hairs (Figure 2E). Only in $C$. saccatum the absorbent root hairs exhibit thickening of the ornamented wall.

Among the Catasetum species, the number of layers of the velamen ranged from five to nine (Figures 1A, 1C, 1D, 1E, 1G, 2A, 2D). Catasetum shimiditianum (Figure 2A) and C. fimbriatum (Figure 2D) displayed from eight to nine cell layers, whereas the majority of the studied species had only five or six layers. In the species C. apolloi (Figure $2 \mathrm{H}$ ) and C. longifolium (Figure $2 \mathrm{G}$ ), tilosomes stem from the cell wall of the velamen and are in direct contact with the exodermal passage cells.

The exodermis is composed of bulky cells with thickened external periclinal and anticlinal walls (Figures 2F, 2G). Most of the exodermal cells have degenerated nuclei and protoplasts. The exodermal passage cells remain alive and bear bulky nucleus and nucleoli (Figure 2F).

In the cortex of the studied species, the cells are isodiametric and compactly arranged, varying in the number of layers, size of the cells, and thickness of the wall (Figures $1 \mathrm{~A}-1 \mathrm{G})$. The cortical parenchyma is made up of 7 to 8 layers in C. fimbriatum (Figure 1B), C. matogrossense (Figure 1D) and C. saccatum (Figure 1E); 10 to 11 layers in C. apolloi (Figure 1A), C. juruenense (Figure 1C), C. schmidtianum (Figure 1G) and C. osculatum and 19 layers in C. longifolium (Figure 1F). Most cells have thick, lignified secondary cell walls (Figures 2I, 2J, 3A, 3B) as identified with an acidphloroglucin and safranin solution. C. apolloi (Figure 1A) and C. longifolium (Figure $1 \mathrm{~F}$ ) are the only species that do not have thick secondary walls in the cortical cells. In $C$. juruenense (Figure 1C) and C. saccatum (Figure 1E), the layers adjacent to the exodermis and the endodermis have small cells with primary walls without lignin. The species $C$. fimbriatum (Figure 1B) and C. schmidtianum (Figure 1G) also have small cells with non-lignified walls; however, these are only present in the layers near the exodermis.

Despite the common occurrence of mycorrhizae in roots of Orchidaceae, they are only present in the species $C$. fimbriatum and C. juruenense (Figure 3C). The endodermis, the innermost layer of the cortex, is unstratified in all species (Figures 3D, 3E, 3F, 4B). In the root endodermis, thin-walled passage cells have thickened periclinal and anticlinal walls and are located opposite to the protoxylem poles. Only in C. matogrossense the endodermal cells have an inverterd U-shaped.

The vascular cylinder is delimited by a uniseriate pericycle with alternating groups of thin-walled and thick-walled cells in all species sampled (Figures 3D, 3E, 3F, 4B). In the roots of all of the species studied, the vascular cylinder has a polyarch structure formed by alternating xylem and phloem strands (Figures 3D-3H, 4A, 4B). We observed an average of 6 to 9 protoxylem poles in C. fimbriatum and $C$. matogrossense (Figure 3D); 11 to 12 poles in C. saccatum, C. shimiditianum and C. juruenense (Figure 3G); 16 to 19 poles in C. osculatum and C. apolloi (Figure 3H); and 24 poles in C. longifolium (Figure 4A).

In the medulla, the central region of the vascular cylinder, the parenchyma cells may be thin-walled (Figures 3D, $3 \mathrm{G}, 3 \mathrm{H}, 4 \mathrm{~A}$ ) or thick-walled (Figure 4B). C. osculatum is the only species with thick secondary tracks (Figure 4C). While idioblasts with flavonoidic crystals are common in all species, idioblasts with raphids form in the cortex of C. schmidtianum, C. matogrossense, C. osculatum and C. saccatum. The histochemical analyses tested negative for starch, lipid droplets, latex, resin duct, and cutin within the roots of all of the sample species. An identification key is provided for the eight species of Catasetum that were studied here, based on the anatomical characteristics of roots that enable species distinction within the genus.
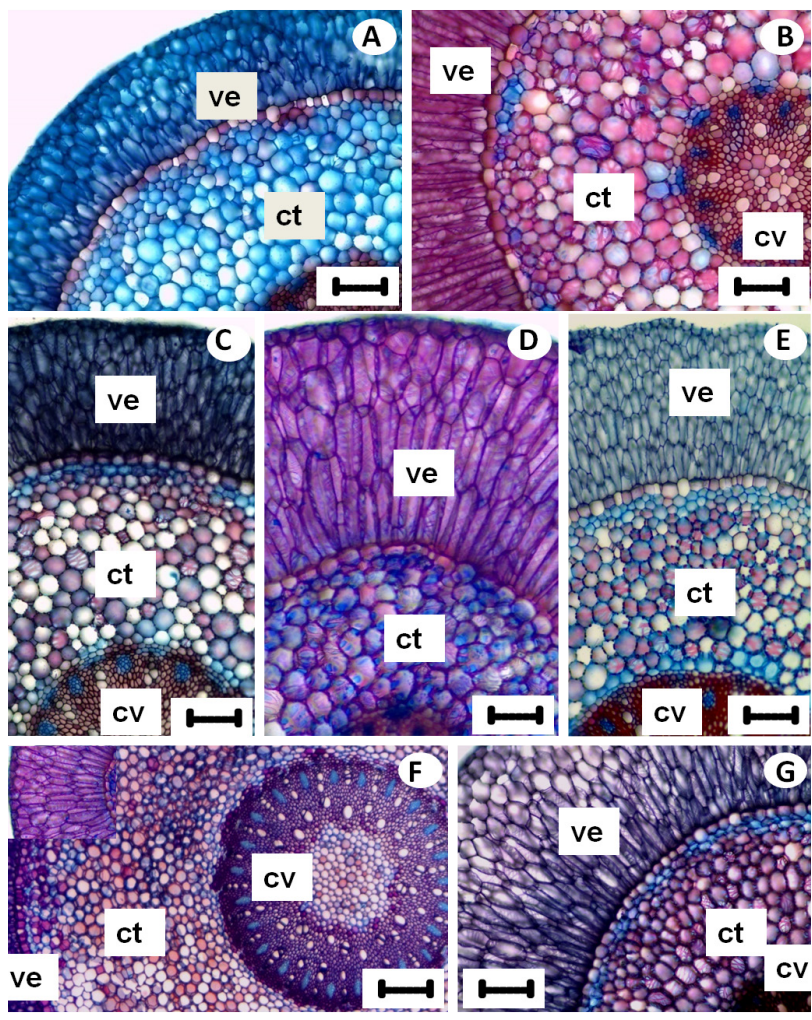

Figure 1. Cross sections of the roots of Catasetum (Orchidaceae). General features of: C. apolloi (A); C. fimbriatum (B); C. juruenense (C); C. matogrossense (D); C. saccatum (E); C. Iongifolium (F); C. schmidtianum (G). (ct-cortex; cv-vascular cylinder; ve-velamen). Scale bars $=130 \mu \mathrm{m}(\mathrm{A}-\mathrm{E}, \mathrm{G})$; $150 \mu \mathrm{m}$ (F). This figure is in color in the electronic version. 


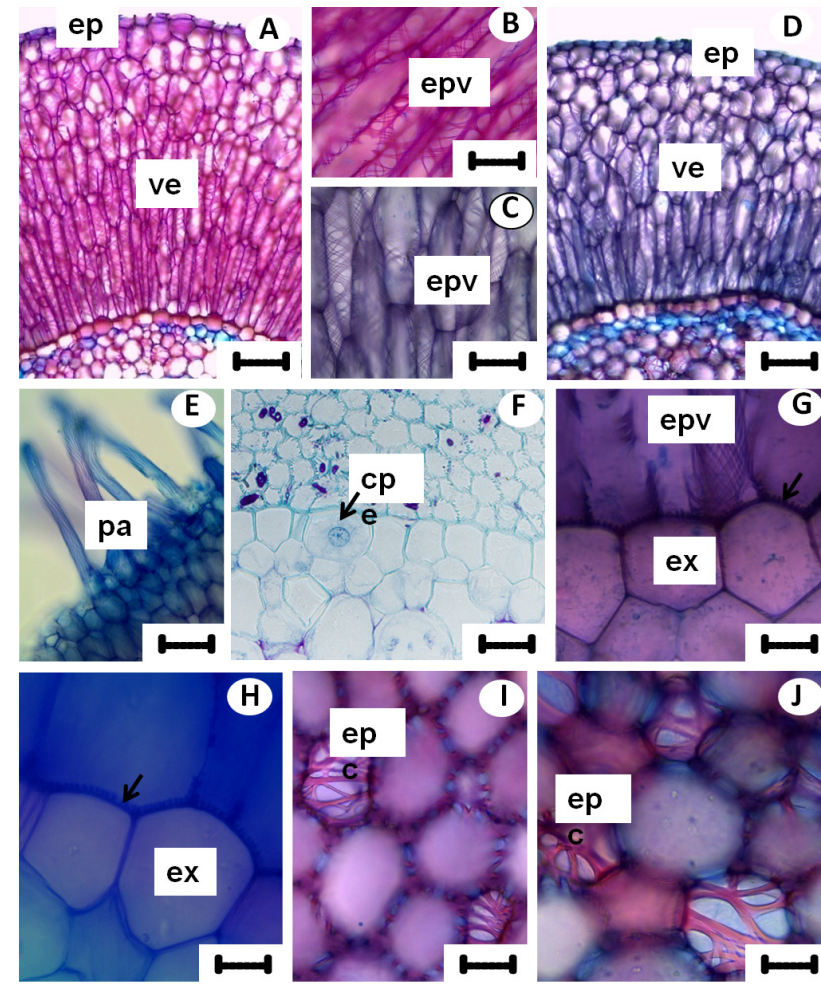

Figure 2. Cross sections of the roots of Catasetum (Orchidaceae). Detailed view of the velamen and exodermis of: $C$. fimbriatum (A, B); C. schmidtianum $(C, D)$; Detailed view of absorbent root hairs of $C$. saccatum $(E)$; Detailed view of tilosomes on the velamen cell walls and of exodermal cell-wall thickening of: C. Iongifolium (F, G); C. apolloi $(\mathrm{H})$; Cortical cells with secondary lignified thickening of: C. schmidtianum (I); C. juruenense (J). (cpe- exodermal passage cells; ep-epivelamen; epc- thickening of cell walls in the cortex; epv- thickening of the velamen cell walls; ex-exodermis; pa- absorbent root hairs; ve-velamen). (arrow=tilosomes). Scale bars $=110 \mu \mathrm{m}(\mathrm{A}, \mathrm{D}) ; 50 \mu \mathrm{m}$ (B, C, F, G, H); 100 $\mu \mathrm{m}(\mathrm{E}) ; 60 \mu \mathrm{m}(\mathrm{I}, \mathrm{J})$. This figure is in color in the electronic version.
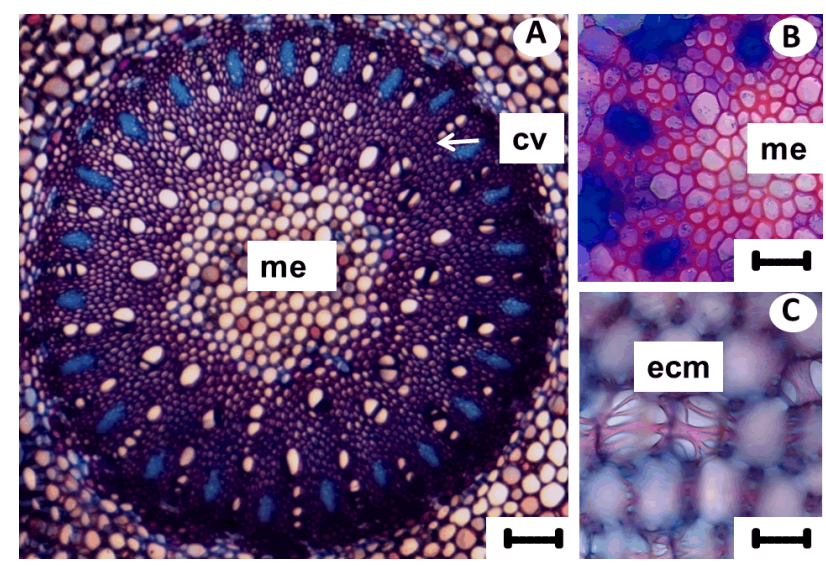

Figure 4. Cross sections of the roots of Catasetum (Orchidaceae). Detailed view of the vascular cylinder of $C$. Iongifolium (A); Detailed view medullary cellwall thickening of: C. matogrossense (B); C. osculatum (C). (ecm-medullary cell-wall thickening; me-medulla). Scale bars $=110 \mu \mathrm{m}(\mathrm{A}) ; 70 \mu \mathrm{m}(\mathrm{B}) ; 60$ $\mu \mathrm{m}(C)$. This figure is in color in the electronic version.

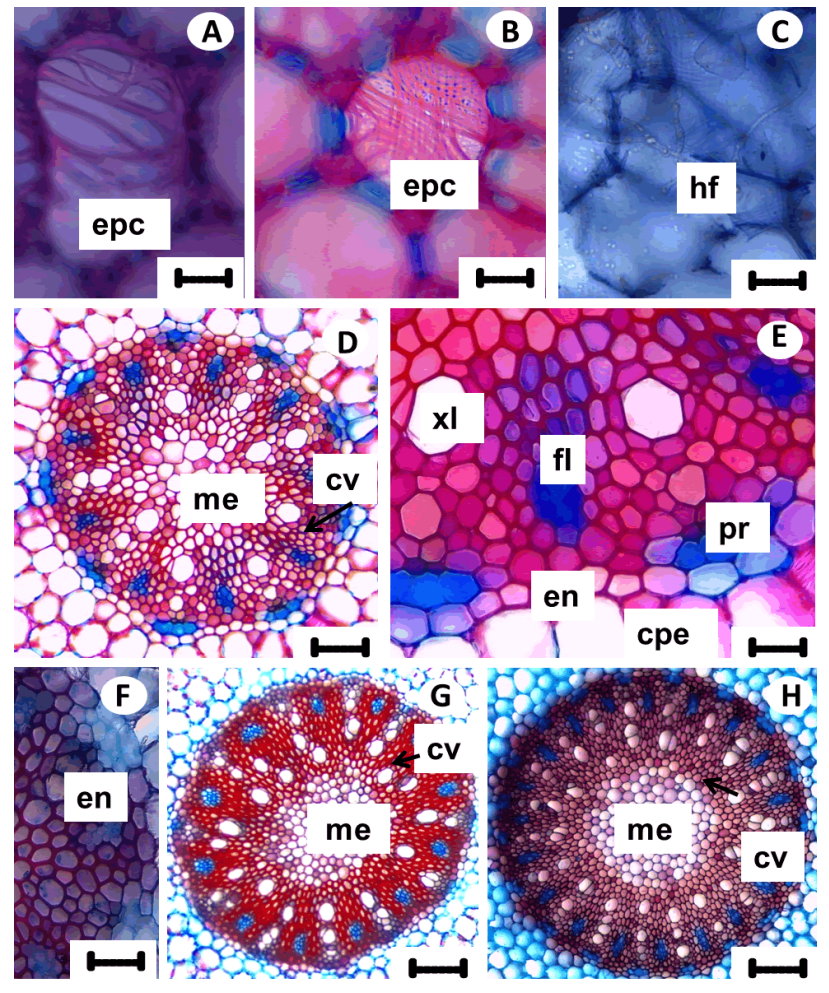

Figure 3. Cross sections of the roots of Catasetum (Orchidaceae). Cortical cells with secondary lignified thickening of: $C$. osculatum (A); C. matogrossense (B); Fungal hyphae in the velamen of $C$. juruenense $(C)$; Detailed view of the vascular cylinder of: C. fimbriatum (D); C. saccatum (G); C. apolloi (H); Detailed view of the endodermis and pericycle of $C$. fimbriatum $(\mathrm{E})$; Detailed view of the endodermis of $C$. matogrossense $(F)$. (cpe-endodermal passage cells; cv-vascular cylinder; en-endodermis; epc-thickening of cell walls in the cortex; fl-phloem; hf-fungal hyphae; me-medulla; pe-pericycle; xl-xylem). Scale bars $=40 \mu \mathrm{m}(\mathrm{A}, \mathrm{B}, \mathrm{C}) ; 100 \mu \mathrm{m}(\mathrm{D}, \mathrm{G}, \mathrm{H}) ; 60 \mu \mathrm{m}(\mathrm{E}) ; 80 \mu \mathrm{m}(\mathrm{F})$. This figure is in color in the electronic version.

\section{Identification key of Catasetum species from the} Portal da Amazônia Region, MT, using anatomical data from the roots.

1. Thick-walled velamen cells and tenuous spirals of cellulosic cell wall material ...................................... 4 1'. Thick-walled velamen cells and tenuous spirals of lignified cell wall material ....................................2

2. Uniseriate endodermis with thick-walled cells with O-shaped and thin-walled passage cells ..............................4 2'. Uniseriate endodermis with thick-walled cells with U-shaped and thin-walled passage cells ....C. matogrossense ...3 3. Presence of mycorrhizae and a vascular cylinder with $-6-9$ protoxylem poles.............................. fimbriatum 3'. Absence of mycorrhizae and a vascular cylinder with $\sim$ 11-12 protoxylem poles.......................... schmidtianum 
4. Cortex with cellulosic thin-walled cells and presence of tilosomes on the cell wall of the velamen...........................6 6 4'. Cortex with thickened lignified cell walls and absence of tilosomes on the cell wall of the velamen.

5. Vascular cylinder with $-11-12$ protoxylem poles. C. apolloi

5'. Vascular cylinder with $>24$ protoxylem poles

C. longifolium

6. Thin-walled cell layers in the cortex adjacent to the exodermis and endodermis, and the remaining with thickened lignified walls; central vascular cylinder with thin-walled cells; and a vascular cylinder with $-11-12$ protoxylem poles.

6'. Thick-walled cell layers with lignified material in the cortex; central vascular cylinder with spirally thickened lignified walls; and vascular cylinder with $\sim 16-19$ protoxylem poles.

C. osculatum

7. Absorbent root hairs with ornamented walls

C. sacatum

7'. Absorbent root hairs without ornamented walls .C.juruenense

\section{DISCUSSION}

We provided here important evidence towards anatomical features that can be considered as strongly associated with the epiphytic habit, using Catasetum, a very representative genus of Amazonian basin, as a case study. Such features include the presence of secondary wall thickening in the cells of the velamen, the exodermis, the cortex, and the medulla. We also identified anatomical markers that can separate some species of this genus. Differentiating such species can be considered a useful tool for taxonomists and other researchers interested in Catasetum; furthermore, new findings regarding this subject may provide important insights for the identification of characteristics that could be used in other taxa. Indeed, it should be considered that the correct taxonomic identification is an essential step in scientific research, mainly in relation to threatened ecosystems such as those found in Amazonian basin. In this study, composition of the thickening of velamen cell walls, ornamentation of absorbent root-hair walls, presence of tilosomes, composition and thickening of the cortical cell walls, presence of mycorrhizae, endodermal cell wall thickening, the number of protoxylem poles, and composition and thickening of the central area of the vascular cylinder were elected as diagnostic features in separating eight species of Catasetum.

The roots studied here have anatomical characters previously described for Orchidaceae in the following ways: multi-layered velamen, uniseriate endodermis and pericycle, polyarch vascular cylinder, and central vascular cylinder with parechymatous, thick-walled cells. These structures characterize the studied species and other Orchidaeceae species examined (Stern and Judd 2001; Silva et al. 2010; Pedrosode-Moraes et al. 2012).

A multistratified velamen occurs in all of the species in our study. In other representatives of Orchidaceae, Araceae, Bromeliaceae, Liliaceae, Dioscoriaceae, Taccaceae, Amarillidaceae and Comellinaceae, the velamen can be singlelayered, bi-layered, or multi-layered (Fahn 1987; Segecin and Scatena 2004). The characteristics that vary the most are cell wall thickness (shape and intensity) and the absence of live protoplasts at maturity of the cells located near the exodermis (Segecin and Scatena 2004).

Spiral thickening in the velamen cell walls, either cellulosic or lignified, as was observed in the studied species, was also reported in previous studies on Catasetum (Stern and Judd 2001; Pedroso-de-Moraes et al. 2012). The composition of the thickening may be important for identifying the species (Benzing et al. 1983), the degree and the composition of the thickening vary among Catasetum species.

The velamen comprises the epivelamen (the outer layer) and the endovelamen (the inner layer) (Sanford and Adanlawo 1973). For the majority of species studied, the peripheral velamen layer differentiates into absorbent epivelamen cells. This characteristic was also reported for other representatives of Catasetinae (Stern and Judd 2001; Silva et al. 2010; Pedroso-de-Moraes et al. 2012). In Clowesia amazonica (Pedroso-de-Moraes et al. 2012) the cells of the epivelamen are the same size of the inner ones, as also reported for some Cymbidieae (Pridgeon et al. 2009), the tribe in which Catasetinae is included. The presence of absorbent root hairs is related to special environmental conditions, including the habit of species (Engard 1944). Just as Silva et al. (2010) demonstrated for other species, the presence of the epivelamen with absorbent root hairs in our species may be interpreted as a strategy to increase the surface area for water absorption.

Absorbent root hairs with thickened, ornamented walls appear to be exclusive to $C$. saccatum and may be considered a diagnostic characteristic for the species. The trait has not been reported in any other Orchidaceae species so far.

Tilosomes on the velamen cell walls in contact with the exodermal passage cells occur only in C. apolloi and C. longifolium studied here, and therefore are considered a diagnostic trait for them. Tilosomes are present in other species of the subfamily Epidendroideae studied (Silva et al. 2010) and absent in other investigated species of Catasetum (Stern and Judd 2001) and in Zygopetalinae species (Stern et al. 2004). Tilosomes almost exclusively occur in epiphytic taxa (Pridgeon et al. 1983). Its function still puzzles researchers. 
A unstratified exodermis with thickened external periclinal cell walls were observed in the eight species studied and have been described in other studies on Catasetinae (Stern and Judd 2001; Pedroso-de-Moraes et al. 2012), and their presence is associated with the response to water loss and greater mechanical protection. A typical single-layered exodermis with passage cells was observed in many of the Orchidaceae roots that have velamen (Benzing et al. 1982; Stern and Whitten 1998; Stern et al. 2004). One of the functions attributed to the exodermis is to decrease water loss by the root (Sanford and Adalawo 1973; Benzing et al. 1982, 1983).

In the studied species, it is possible to differentiate the cortical region taking into consideration the composition of the cell wall thickening. Secondary lignified thickening in most of the cell walls was observed in six of the studied species, but not in C. apolloi and C. longifolium. This trait is common in the leaves of many Orchidaceae (Silva et al. 2006), but not as common in the roots. For Catasetum, this feature was reported for many previously studied species (Stern and Judd 2001; Pedroso-de-Moraes et al. 2012), and is therefore considered important for characterizing the genus.

The presence of cell layers adjacent to the exodermis and endodermis with cells smaller than cortical cells region was previously reported for Catasetinae (Stern and Judd 2001; Pedroso-de-Moraes et al. 2012). However, cellulosic primary walls near the exodermis and/or endodermis and thickened lignified secondary walls in the remaining layers were not described by these authors.

Idioblasts whith raphids or with a single crystal were also detected, with raphides occurring more commonly in Orchidaeceae, particularly in the roots (Stern 1997b; Stern et al. 2004; Pedroso-de-Moraes et al. 2012). Idioblasts containing flavonoids have been reported for Catasetum and Cychnochese (Pedroso-de-Moraes et al. 2012) and were also identified the species we studied. The authors suggest that the presence of this type of idioblast is useful in distinguishing among the genera of Catasetinae as proposed by OliveiraPires et al. (2003) for Laelinae (Orchidaceae). The flavonoid crystals are associated with various factors including infection, temperature, nutrition, lesions, nitrogen fixation, and radiation quantity (Blank 1947), and can occur in all of the plant's organs (Zuanazzi 2001) but mainly in those most exposed to light (Bohm 1987).

Mycorrhizae occur in only two of the species, resembling the pelotons described by Hadley and Williamson (1972) and Benzing and Friedman (1981). It could be inferred that the fungi persist only in mature individuals of $C$. fimbriatum and $C$. juruenense and that these species can obtain nitrogen and other substances from degrading pelotons.

Orchidaceae may be classified in 12 types depending on the occurrence and combination of the following characteristics
(Porembski and Barthlott 1988): epivelamen, number of layers, and type of thickening in velamen cell walls in the exodermis, and number of layers in the cortex. The species studied are of the Cymbidium-type since they have an epivelamen, thickened external exodermal cells with periclinal walls and a cortex with more than seven cell layers. These anatomical features support the classification of Chase et al. (2003) that recognize only Cymbidieae as a single monophyletic tribe, consisting of Catasetinae, Coeliopsidinae, Cyrtopodiinae, Cymbidiinae, Eriopsidinae, Eulophiinae, Maxillariinae, Oncidiinae, Stanhopeinae, Vargasieliinae, and Zygopetalinae.

The species examined in this study have roots with a uniseriate endoderm and pericycle, which is consistent with other species of Orchidaceae (Pridgeon and Stern 1982; Silva et al. 2010; Pedroso-de-Moraes et al. 2012). The polyarch xylem is also common in other Orchidaceae, with the number of poles varying in different roots of the same species and even in different sections of the same root (Silva et al. 2010). This was verified for all of the species in this study.

As in other Orchidaceae, the central vascular cylinder is identified as the medulla (Oliveira and Sajo 1999; Silva et al. 2010; Pedroso-de-Moraes et al. 2012), which is composed of thin- or thick-walled parenchyma. Among the studied species, only C. osculatum has a medulla with spirally thickened cell walls, this trait being an important anatomical marker used to distinguish this species. This characteristic is present in all 12 species studied by Pedroso-de-Moraes et al. (2012). These authors also verified the presence of starch in the medulla of the species Cycnoches loddigesi, Mormodes elegans, and Mormodes tapoayensis. The presence of starch in two Mormodes species may be useful for characterizing this genus (Pedrosode-Moraes et al. (2012). In the case of the Catasetum species studied here, starch was not detected through specific tests, consistent with the results for the species studied (Pedrosode-Moraes et al. 2012).

The adaptations to the epiphytic habit that we found in this study, named, the presence of secondary wall thickening in the cells of the velamen, the exodermis, the cortex, and the medulla, may enable the dispersal into extreme environments, representing ancestral adaptations selected during the diversification rather than adaptations interpreted as features related to a particular environment where the species currently persists. The complexity of the thickened walls in the velamen and exodermis were correlated with the epiphytic habit (Tomlinson 1969; Stern and Judd 2001; Silva et al. 2010; Pedroso-de-Moraes et al. 2012).

\section{CONCLUSION}

The examined species of Catasetum share several root anatomical features, and some species have adaptations to the epiphytic habit. Some characteristics were considered to 
be anatomical markers, such as composition and thickening of the velamen cell wall, wall ornamentation of the absorbent root hairs, presence of tilosomes, composition and thickening of the cortical cell wall, presence of mycorrhizae, type of thickening in the endodermal cell wall, number of protoxylem poles, and composition and type of thickening in the central vascular cylinder. These markers enabled us to categorize the species within the genus and provide a dichotomous key for identification of Catasetum in the Portal da Amazônia region, thereby providing a useful tool for taxonomists of this group and insights for development of new researches in this subject. Since the taxonomic knowledge is essential to biodiversity inventories, the legacy provided by this pioneer work may add efforts in preserving the biological heritage of Amazonian basin.

\section{ACKNOWLEDGMENTS}

We would like to thank the Fundação de Amparo à Pesquisa do Estado de Mato Grosso (FAPEMAT) for financial support (Grant number 732482/2008) and Universidade do Estado de Mato Grosso for the scholarship to the second author. The authors acknowledge Glenn Hawes, M.Ed. English, the University of Georgia, USA, for editing this manuscript.

\section{REFERENCES}

Benzing, D.H.; Friedman, W.E. 1981. Mycotrophy: its occurrence and possible significance among epiphytic Orchidaceae. Selbyana, 5: 243-247.

Benzing, D.H.; Ott, D.W.; Friedman, W.E. 1982. Roots of Sobralia macrantha (Orchidaceae): structure and function of the velamenexodermis complex. American Journal of Botany, 69: 608-614.

Benzing, D.H.; Friedman, W.E.; Peterson, G.; Renfrow, A. 1983. Shootlesness, velamentous roots, and the permanence of Orchidaceae in the epiphytic biotope. American Journal of Botany, 70: 121-133.

Blank, F. 1947. The anthocyanin pigments of plants. Botanical Research, 13: 241-317.

Bohm, B.A. 1987. Intraspecific flavonoid variation. Botanical Research, 53: 197-279.

Chase, M.W.; Freudenstein, J.V.; Cameron, K.M.; Barrett, R.L. 2003. DNA data and Orchidaceae systematics: a new phylogenic classification. In: Dixon, K., Kell, S.P., Barrett, R.L. \& Cribb, P.J. (Eds). Orchid conservation. Kota Kinabalu: Natural History Publications, p.69-89.

Costa, A.F. 1972. Farmacognosia (Farmacognosia Experimental). Fundação Calouste Gulbenkian, Lisboa. 1033p.

Costa, A.F. 1982. Farmacognosia. 2ed. Fundação Calouste Gulbenkian, Lisboa. 1117p.

Costa, S.M.O.; Lemos, T.L.G.; Deusdênia, O.; Pessoa, L.; Assunção, J.C.C.; Braz-Filho, R. 2002. Constituintes químicos de Lippia sidoides (Cham.) Verbenaceae. Revista Brasileira de Farmacognosia, 12: 66-67.
Engard, C.J. 1944. Morphological identity of the velamen and exodermis in orchids. Botanical Gazette, 105: 457-462.

Englert, S.I. 2000. Orquideas e Bromélias: manual prático de cultivo. Agropecuária, Guaíba-RS, 2000. 92p.

Fahn, A. 1987. Plant anatomy. 3 ed., Pergamon Press, Oxford, 1987. 555p.

Hadley, G.; Williamson, B. 1972. Features of mycorrhizal infection in some malayan orchids. New Phytologist, 71: 1111-1118.

Johansen, D.A. 1940. Plant microtechnique. McGraw-Hill Book Co. Inc., New York. 523p.

Kaiser, E. 1880. Verfahren zur Herstellung einer tadellosen GlycerinGelatine. Botanisch Zentralb, 1880: 25-26.

Langeron, M. 1949. Précis de microscopie. Masson et Cie, Libraires de L'Académie de Medicine, Saint-Germain, Paris, 1.

Oliveira, V.C.; Sajo, M.G. 1999. Root anatomy of nine Orchidaceae species. Brazilian Archives of Biology and Technology, 42: 405-413.

Oliveira-Pires, M.F.; Semir, J.; Melo de Pinna; G.F.A.; Felix, L. 2003. Taxonomic separation of the genera Prosthechea and Encyclia (Liliinae Orchidaceae) using leaf and root anatomical features. Botanical Journal of the Linnean Society, 143: 293-303.

Pedroso-de-Moraes, C.; Souza-Leal, T.; Brecansini, R.; Pettini-Benelli, A.; Sajo, M.G. 2012. Radicular anatomy of twelve representatives of the Catasetinae subtribe (Orchidaceae: Cymbidieae). Anais da Academia Brasileira de Ciências, 84: 455-467.

Pridgeon, A.M.; Stern, W.L. 1982. Vegetative anatomy of Myoxanthus (Orchidaceae). Selbyana, 7: 55-63.

Pridgeon, A.M.; Stern, W.L.; Benzing, D.H. 1983. Tilosomes in roots of Orchidaceae: morphology and systematic occurrence. American Journal of Botany, 70: 1365-1377.

Pridgeon, A.M.; Cribb, P.J.; Chase, M.A.; Rasmussen, F.N. 2009. Genera Orchidacearum. vol. 5: Epidendroideae (part two). Oxford University Press, Oxford. 585p.

Porembski, S.; Barthlott, W. 1988. Velamen radicum micromorphology and classification of Orchidaceae. Nord Journal Botany, 8: 117-137.

Sanford, W.W.; Adanlawo, I. 1973. Velamen and exodermis characters of West African epiphytic orchids in relation to taxonomic grouping and habitat tolerance. Botanical Journal of the Linnean Society, 66: 307-321.

Segecin, S.; Scatena, V.L. 2004. Morfoanatomia de rizomas e raízes de Tillandsia L. (Bromeliaceae) dos Campos Gerais, PR, Brasil. Acta Botanica Brasilica, 18: 253-260.

Silva, I.V.; Meira, R.M.S.A.; Azevedo, A.A.; Euclydes, R.M.A. 2006. Estratégias anatômicas foliares de treze espécies de Orchidaceae ocorrentes em um campo de altitude no Parque Estadual da Serra do Brigadeiro (PESB) - MG, Brasil. Acta Botanica Brasilica, 20: 741-750.

Silva, I.V.; Meira, R.M.S.A.; Azevedo, A.A. 2010. Anatomia de raízes de espécies de Orchidaceae do Parque Estadual da Serra do Brigadeiro, Minas Gerais. Hoehnea, 37: 147-161

Stern, W.L. 1997b. Vegetative anatomy of subtribe Habenariinae (Orchidaceae). Botanical Journal of the Linnean Society, 125: 211-227. 
Stern, W.L.; Whitten, W.M. 1998. Comparative vegetative anatomy of Stanhopeinae (Orchidaceae). Botanical Journal of the Linnean Society, 129: 87-103.

Stern, W.L.; Judd, W.S. 2001. Comparative anatomy and systematic of Catasetinae (Orchidaceae). Botanical Journal of the Linnean Society, 136: 153-178.

Stern, W.L.; Judd, W.S.; Carlsward, B.S. 2004. Systematic and comparative anatomy of Maxillarieae (Orchidaceae), sans Oncidiinae. Botanical Journal of the Linnean Society, 144: 251-274.
Tomlinson, P.B. 1969. III- Commelinales-Zingiberales. In: Metcalfe, C.R. (Ed.). Anatomy of the Monocotyledons. Clarendon Press, Oxford.Vol. 3, p. 1-446.

Zuanazzi, J.A.S. 2001. Flavonóides. In: Simôes, C.M.O; Schenkel, E.P.; Gosman, G.; Palazzo, J.C.; Mentz, L.A. and Petrovick, P.R. (Org). Farmacognosia: da planta ao medicamento. Editora da UFRGS/Editora da UFSC, Porto Alegre. p. 499-526.

Recebido em 07/05/2014

Aceito em 24/07/2014 